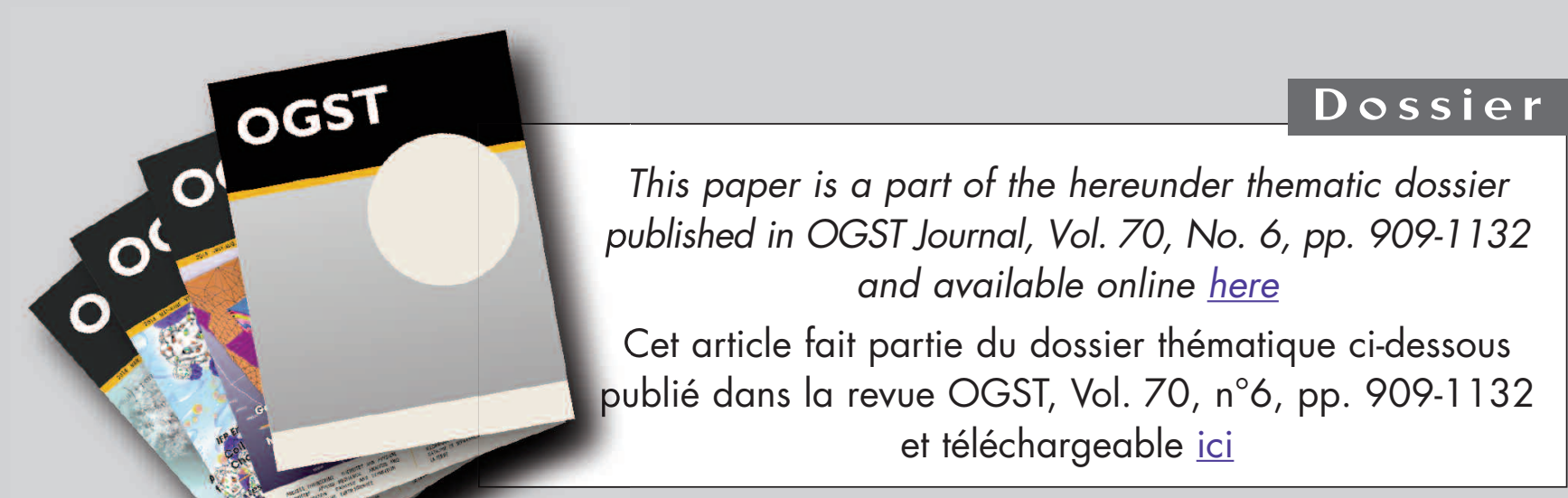

Oil \& Gas Science and Technology - Rev. IFP Energies nouvelles, Vol. 70 (2015), No. 6, pp. 909-1132

Copyright (C) 2015, IFP Energies nouvelles

909 > Editorial - Enhanced Oil Recovery (EOR), Asphaltenes and Hydrates Éditorial - EOR «récupération assistée du pétrole», Asphaltènes et Hydrates D. Langevin and F. Baudin

\section{ENHANCED OIL RECOVERY (EOR)}

917 > HP-HT Drilling Mud Based on Environmently-Friendly Fluorinated Chemicals Boues de forage HP/HT à base de composés fluorés respectueux de I'environnement

I. Henaut, D. Pasquier, S. Rovinetti and B. Espagne

931 > Effective Viscosity in Porous Media and Applicable Limitations for Polymer Flooding of an Associative Polymer

Viscosité effective dans des médias poreux et limites d'application de l'injection de polymères associatifs

P. Zhang, Y. Wang, Y. Yang, W. Chen and S. Bai

$941>$ Dynamic Gelation of HPAM/Cr(III) under Shear in an Agitator and Porous Media Gélification dynamique de HPAM/Cr(III) sous cisaillement dans un agitateur et en milieu poreux

Y. Haiyang, W. Yefei, Z. Jian, L. Peng and S. Shenglong

$951>$ Computer Modeling of the Displacement Behavior of Carbon Dioxide in Undersaturated Oil Reservoirs

Modélisation par ordinateur du comportement de déplacement du dioxyde de carbone dans des réservoirs d'huile non saturés

B. Ju, Y.S. Wu and J. Qin

$967>$ Predicting CO, Minimum Miscibility Pressure (MMP) Using Alternating Conditional Expectation (ACE) Algorithm

Prédiction de la pression miscibilité minimum (MMP) du CO en utilisant un algorithme basé sur l'ACE (Alternating Conditional Expectation)

0 . Alomair, A. Malallah, A. Elsharkawy and M. Iqbal

983 > Towards the Development of Bitumen Carbonates: An Integrated Analysis of Grosmont Steam Pilots

Vers le développement des carbonates bitumineux : une analyse intégrée des pilotes vapeur de Grosmont

C.C. Ezeuko, J. Wang, M.S. Kallos and I.D. Gates

1007> A Novel Model of Foam Flooding Considering Multi-Factors for Enhancing Oil Recovery

Un nouveau modèle d'injection de mousse considérant de multiples facteurs afin d'améliorer la récupération de pétrole

J. Wang, H. Liu, H. Zhang, G. Zhang, P. Liu and K. Sepehrnoori
1025> Testing of Snorre Field Foam Assisted Water Alternating Gas (FAWAG) Performance in New Foam Screening Model

Vérification des performances de la méthode FAWAG (Foam Assisted Water Alternating Gas) sur le champ de Snorre, en Norvège, avec un nouveau modèle de sélection des mousses

P. Spirov and S. Rudyk

\section{ASPHALTENES}

1035> Structural Study of Asphaltenes from Iranian Heavy Crude Oil Étude structurale d'asphaltènes de pétrole brut lourd iranien L. Davarpanah, F. Vahabzadeh and A. Dermanaki

$1051>$ Experimental Study and Mathematical Modeling of Asphaltene Deposition Mechanism in Core Samples

Étude expérimentale et modélisation mathématique du mécanisme de déposition d'asphaltène dans des carottes de forage

T. Jafari Behbahani, C. Ghotbi, V. Taghikhani and A. Shahrabadi

1075> Prediction of the Gas Injection Effect on the Asphaltene Phase Envelope Prévision Prévision de l'effet d'injection de gaz sur l'enveloppe de phase des asphaltènes P. Bahrami, R. Kharrat, S. Mahdavi and H. Firoozinia

\section{HYDRATES}

1087> Methane Hydrate Formation and Dissociation in the Presence of Silica Sand and Bentonite Clay

Formation et dissociation d'hydrates de méthane en présence de sable de silice et d'argile de bentonite

V. Kumar Saw, G. Udayabhanu, A. Mandal and S. Laik

$1101>$ Prediction of Mass Flow Rate in Supersonic Natural Gas Processing Prédiction du débit massique dans les applications de traitement supersonique du gaz naturel

C. Wen, X. Cao, Y. Yang and Y. Feng

$1111>$ Experimental Study on Hydrate Induction Time of Gas-Saturated Water-in-Oil Emulsion using a High-Pressure Flow Loop

Étude expérimentale sur le temps d'induction d'hydrate d'une émulsion eau-enhuile saturée en gaz en utilisant une boucle à circulation sous haute pression X.F. Lv, B.H. Shi, Y. Wang, Y.X. Tang, L.Y. Wang and J. Gong

1125> Hollow Silica: A Novel Material for Methane Storage La silice creuse : un nouveau matériau pour le stockage de méthane V.D. Chari, P.S.R. Prasad and S.R. Murthy 


\title{
Methane Hydrate Formation and Dissociation in the Presence of Silica Sand and Bentonite Clay
}

\author{
V. Kumar Saw ${ }^{1}$, G. Udayabhanu ${ }^{2}$, A. Mandal ${ }^{1 *}$ and S. Laik \\ ${ }^{\prime}$ Gas Hydrate Laboratory, Department of Petroleum Engineering, Indian School of Mines, Dhanbad, 826004 - India \\ ${ }^{2}$ Department of Applied Chemistry, Indian School of Mines, Dhanbad, 826004 - India \\ e-mail: mandal_ajay@hotmail.com \\ * Corresponding author
}

\begin{abstract}
The formation and dissociation of methane hydrates in a porous media containing silica sand of different sizes and bentonite clay were studied in the presence of synthetic seawater with $3.55 \mathrm{wt} \%$ salinity. The phase equilibrium of methane hydrate under different experimental conditions was investigated. The effects of the particle size of silica sand as well as a mixture of bentonite clay and silica sand on methane hydrate formation and its dissociation were studied. The kinetics of hydrate formation was studied under different subcooling conditions to observe its effects on the induction time of hydrate formation. The amount of methane gas encapsulated in hydrate was computed using a real gas equation. The Clausius-Clapeyron equation is used to estimate the enthalpy of hydrate dissociation with measured phase equilibrium data.
\end{abstract}

Résumé - Formation et dissociation d'hydrates de méthane en présence de sable de silice et d'argile de bentonite - La formation et la dissociation d'hydrates de méthane dans un milieu poreux contenant du sable de silice de différentes tailles et de l'argile de bentonite ont été étudiées en présence d'eau de mer synthétique de 3,55\% poids de salinité. L'équilibre de phase des hydrates de méthane sous différentes conditions expérimentales a été étudié. Les effets de la taille des particules de sable de silice ainsi que ceux d'un mélange d'argile de bentonite et de sable de silice sur la formation d'hydrates de méthane et leur dissociation ont été étudiés. La cinétique de la formation d'hydrates a été étudiée sous différentes conditions de sousrefroidissement pour observer ses effets sur le temps de latence de la formation d'hydrates. La quantité de méthane encapsulée dans des hydrates a été calculée en utilisant une équation de gaz réel. L'équation de Clausius-Clapeyron est utilisée pour déterminer l'enthalpie de la dissociation des hydrates avec des données mesurées d'équilibre de phase. 


\section{INTRODUCTION}

Hydrates are thermodynamically stable if the pressure is greater than the equilibrium pressure at a given sediment temperature [1-3]. In addition to favorable temperature and pressure conditions, water salinity changes the stability conditions of gas hydrate in marine sediments [4-7]. Understanding the role of the sediment matrix in gas hydrate formation is crucial to elucidate the formation mechanisms and accumulation of methane hydrate in natural environments. Studies show that the type of medium strongly affects the formation and dissociation processes of natural gas hydrate [8-10]. Experiments have been conducted to understand the distribution of natural gas hydrate in sediments. Handa and Stupin [8] showed that the dissociation pressure of methane and propane hydrates in porous media with small pores was higher than that of those in bulk. Uchida et al. [9] studied the effects of different media such as sand, sandstone, glass beads and clays on methane hydrate formation. They indicated that the equilibrium conditions of gas hydrates within these media were affected mainly by pore sizes and, to a lesser degree, by surface textures and mineral components. Li et al. [11] and Guanli et al. [12] reported that hydrate formation media significantly affect the formation of gas hydrates. They also reported that the smaller the particle size of the media, the harder the methane hydrate formation within it. Oceanic gas hydrates are commonly found in sand- or clay-type sediments. The capillary inhibition of hydrate stability in narrow pores, such as fine-grained silts, muds and clays, has been considered to explain differences between predicted and actual hydrate stability zones in ocean sediments, while the equilibrium pressure for hydrate dissociation and the thermodynamic properties in large pores of coarse-grained sand sediment are nearly identical to those in the pure bulk water phase [13]. Gas hydrate stability in the ocean sediment is affected by electrolytes dissolved in seawater. Therefore, it is essential to consider the combined effects of both pores and electrolytes to predict an accurate gas hydrate stability zone in the ocean sediment. Kang and Lee [14] investigated the phase equilibria and formation kinetics of synthetic natural gas in porous silica gel. It is found that the hydrate-phase equilibria are shifted to the inhibition zone more than those in the bulk phase. The inhibition effect is more pronounced in the meso-sized pores than the macro-sized ones. Subsequently, Li and Zhang [15] also studied the dissociation kinetics of methane hydrate in silica gels as porous media. The results reveal that the rate of methane released from the hydrate dissociation increases with an increase in the initial formation pressure, decrease in the environmental temperature and increase in pore size. In subsea environments, the sediments are normally saturated with seawater. Natural marine sediment is saturated with aqueous solution of salinity $3.55 \mathrm{wt} \%$ TDS $[16,17]$. The equilibrium conditions for the formation and dissociation of methane hydrates can be influenced by the interlayer structure and surface chemistry of the host sediments. The effects of sediment surface chemistry are largely unknown.

The objective of the present study is to observe the effects of silica sand and bentonite clay suspended in synthetic seawater of salinity $3.55 \%$ on the phase equilibrium of methane hydrate, to predict the formation and dissociation characteristics of methane hydrate in natural environments. This work is focused on the effects of silica sand and its size as well as a mixture of silica sand and bentonite clay on methane hydrate formation and dissociation. The kinetics of hydrate formation was also studied to observe the induction time of hydrate formation, which is a very important parameter of hydrate formation.

\section{EXPERIMENTAL SET-UP, MATERIALS AND PROCEDURE}

\subsection{Apparatus}

The schematic diagram of the gas hydrate autoclave apparatus is shown in Figure 1. The high-pressure hydrate autoclave procured from Vinci Technology, France, was used to study gas hydrate formation and dissociation. The apparatus measures the induction time of hydrate formation and pressure as a function of time during hydrate formation, and takes video graphs during the experiments. The system consists of a constant volume hydrate cell with $250 \mathrm{~cm}^{3}$ capacity. The cell temperature is controlled by a thermostatic bath. A thermocouple measures the temperature of the cell with an

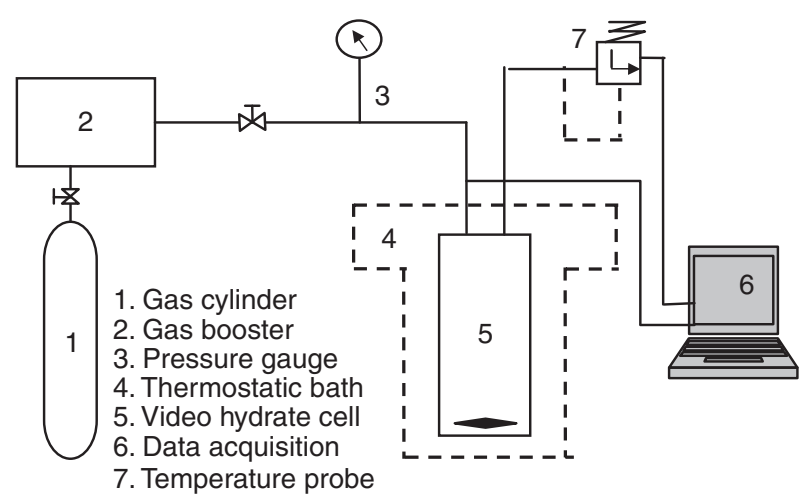

Figure 1

Schematic of gas hydrate autoclave apparatus. 
accuracy of $0.1{ }^{\circ} \mathrm{C}$. The cell pressure is monitored by a pressure transducer. A magnetic stirrer is used to agitate the test fluid. A computer is connected to the hydrate cell for acquisition of temperature and pressure versus time data.

\subsection{Materials}

All the experiments were carried out with $99.99 \%$ pure methane (procured from Chemtron Science Laboratory, Navi Mumbai, India) and reverse osmosis water from the Millipore water system (Millipore $S A$, Molshein, France). Silica sand was purchased from Sigma Aldrich, Germany. The different salts (purity 98-99.9\%) used for preparing synthetic seawater were procured from Merck Specialities Pvt. Ltd., Mumbai, India. Three particle size ranges of sand, as given in Table 1, were obtained by sieving.

The bentonite clay was supplied by Central Drug House, New Delhi, India. The Particle Size Distribution (PSD) of the bentonite clay suspension was studied using a Nano-S90 Zetasizer Ver. 6.34 from Malvern Instruments $L t d$. Three peaks (Fig. 2) are observed of different intensity and volume with mean sizes of $505 \mathrm{~nm}(42.2 \%)$, $62.93 \mathrm{~nm}(25.9 \%)$, and $2590 \mathrm{~nm}(9.4 \%)$. Bentonite clay particles distributed in water ranges in size from $30 \mathrm{~nm}$ to $3200 \mathrm{~nm}$ with an average size of $279.8 \mathrm{~nm}$. The results of the PSD analysis are given in Table 2.

\subsection{Experimental Procedure}

The cell was filled with a test sample $(130 \mathrm{cc})$ with a fixed composition of bentonite clay and silica sand

TABLE 1

Grain Size (diameter) Range (GSR) of silica sand

\begin{tabular}{c|c}
\hline Mesh size & GSR $(\mu \mathrm{m})$ \\
\hline $30-50$ & $500-300$ \\
\hline $52-60$ & $300-250$ \\
\hline $60-100$ & $250-150$ \\
\hline
\end{tabular}

prepared in synthetic seawater $(3.55 \%$ TDS $)$ and immersed in a temperature-controlled bath to maintain the constant temperature of the cell. The liquid in the bath is a mixture of water and ethylene glycol $(25 \%)$. Before charging with methane gas, the cell was evacuated by a vacuum pump. The cell was then pressurized with methane gas up to the desired pressure. The cell was cooled step-wise in the programmable bath and sufficient time (1-2 hours) was given to attain the equilibrium condition at each temperature. The hydrate formation was observed with a sudden sharp pressure drop under constant cell temperature and an online video picture. After hydrate formation, the entire cell was heated slowly $(1 \mathrm{~K} / \mathrm{h})$ so that the equilibrium of the system was not disturbed. Dissociation of the hydrate was observed with substantial increase in pressure. The process of dissociation is assumed to be complete at the temperature where the formationdissociation loop is closed. The temperature and
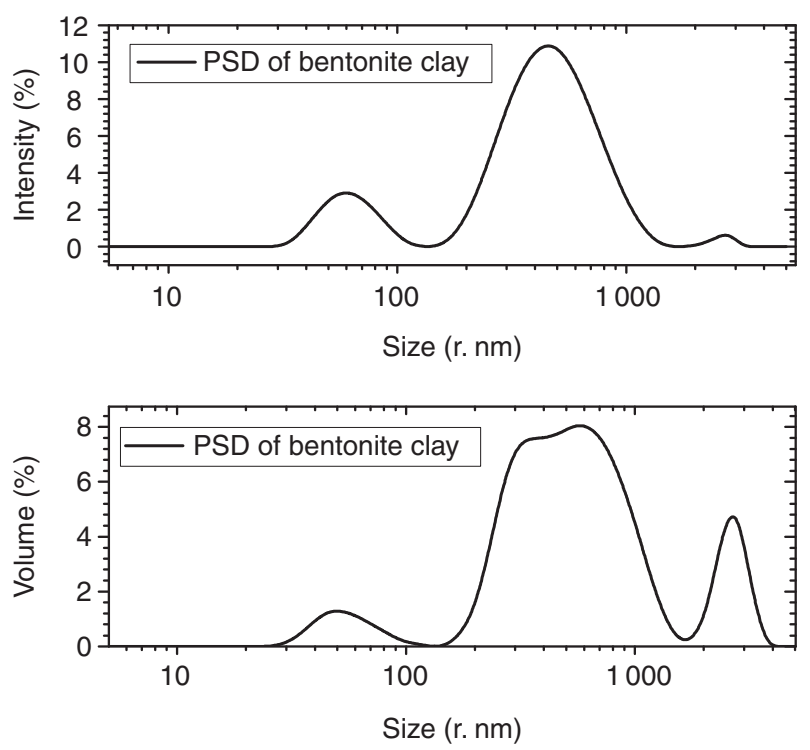

Figure 2

PSD of bentonite clay in aqueous suspension.

TABLE 2

PSD results of bentonite clay in water

\begin{tabular}{c|c|c|c|c}
\hline Peak (s) & Size (r.nm) & \% Intensity & $\sigma$ & 16.33 \\
\hline Peak 1 & 62.93 & 14.4 & 213.3 & 42.2 \\
\hline Peak 2 & 505.0 & 84.2 & 243.1 & 25.9 \\
\hline Peak 3 & 2590.0 & 1.4 & 9.4 \\
\hline
\end{tabular}




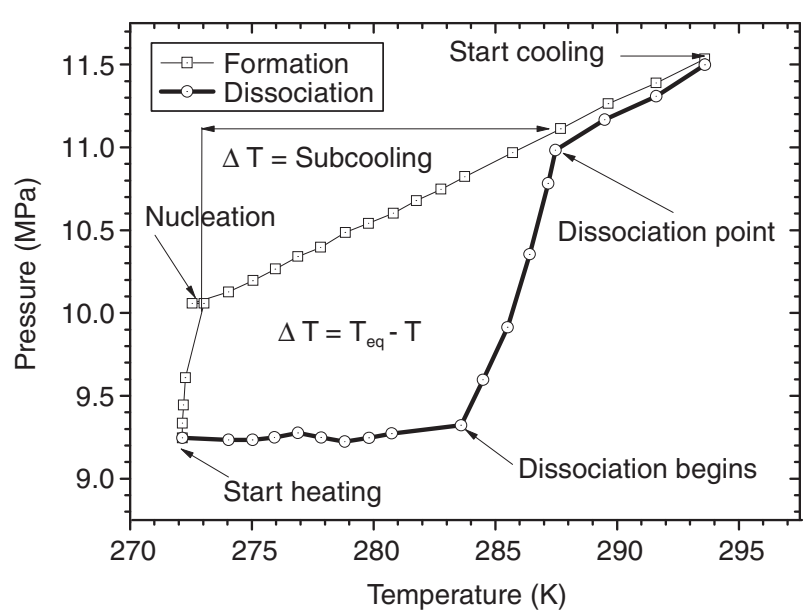

Figure 3

Pressure temperature profile of methane hydrate formation and dissociation in $10 \%$ silica sand (mesh size 30-52) in Synthetic SeaWater (SSW).

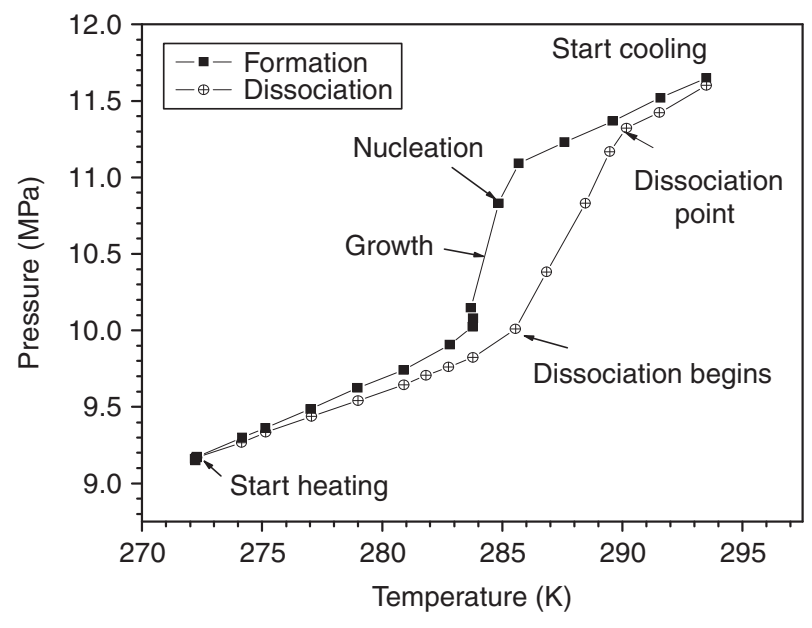

Figure 4

Pressure temperature profile of methane hydrate formation and dissociation in the presence of $10 \%$ bentonite clay.

TABLE 3

Nucleation temperature, initial cell pressure, growth temperature and pressure drop during hydrate formation in the presence of silica sand. SSW: Synthetic SeaWater

\begin{tabular}{l|c|c|c|c}
\hline \multicolumn{1}{c|}{ Test sample } & $\begin{array}{c}\text { Initial cell pressure } \\
(\mathrm{MPa})\end{array}$ & $\begin{array}{c}\text { Nucleation temperature } \\
(\mathrm{K})\end{array}$ & $\begin{array}{c}\text { Growth temperature } \\
(\mathrm{K})\end{array}$ & $\begin{array}{c}\text { Pressure drop } \Delta P \\
(\mathrm{MPa})\end{array}$ \\
\hline $10 \%$ bentonite in SSW & 11.54 & 284.85 & 272.19 & 1.13 \\
\hline $\begin{array}{l}10 \% \text { silica sand } \\
\text { (mesh size 32-52) in SSW }\end{array}$ & 11.54 & 272.27 & 0.49 \\
\hline $\begin{array}{l}10 \% \text { silica sand } \\
(\mathrm{mesh} \text { size 52-60) in SSW }\end{array}$ & 11.54 & 272.20 & 272.0 & 0.58 \\
\hline $\begin{array}{l}10 \% \text { silica sand } \\
(\mathrm{mesh} \text { size 60-100) in SSW }\end{array}$ & 11.54 & 271.99 & 271.99 & 0.59 \\
\hline
\end{tabular}

pressure data during the experiments were stored in the computer and also displayed as online graphs. In the present study, methane hydrate formation was observed in the presence of silica sand in synthetic seawater (3.55\% TDS) and also with a process sample with a mixture of both bentonite clay and silica sand. Variation in the size of silica sand was found to have an effect on hydrate formation as well as on dissociation. During the experiments, the reaction medium was agitated using a magnetic stirrer at a constant rate (1000 RPM). An experiment was also performed with $10 \%$ bentonite clay to compare the results obtained for hydrate formation and dissociation in the presence of silica sand, and of both bentonite clay and silica sand.

\section{RESULTS AND DISCUSSION}

\subsection{Formation of Hydrate in the Presence of Silica Sand}

Figure 3 shows the conversion of water and methane into hydrate in the presence of silica sand and its reverse process. It can be noted that hydrate formation is initiated at 272.27 K with a sharp drop in pressure. This temperature is maintained until no pressure drop is observed, indicating complete formation of hydrate. Under similar conditions of temperature (293.5 K) and pressure (11.65 MPa), an experiment was carried out with bentonite clay. In this case, hydrate formation begins at $284.85 \mathrm{~K}$, which is 12.58 K higher (Fig. 4, Tab. 3). 


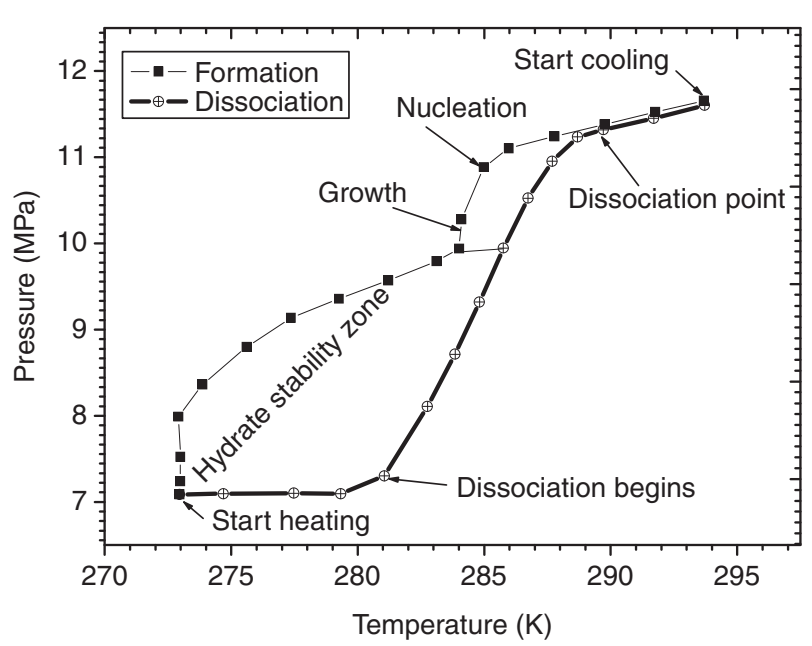

Figure 5

Pressure temperature profile of methane hydrate formation and dissociation in the presence of $10 \%$ bentonite clay and $10 \%$ silica sand (mesh size $30-52$ ).

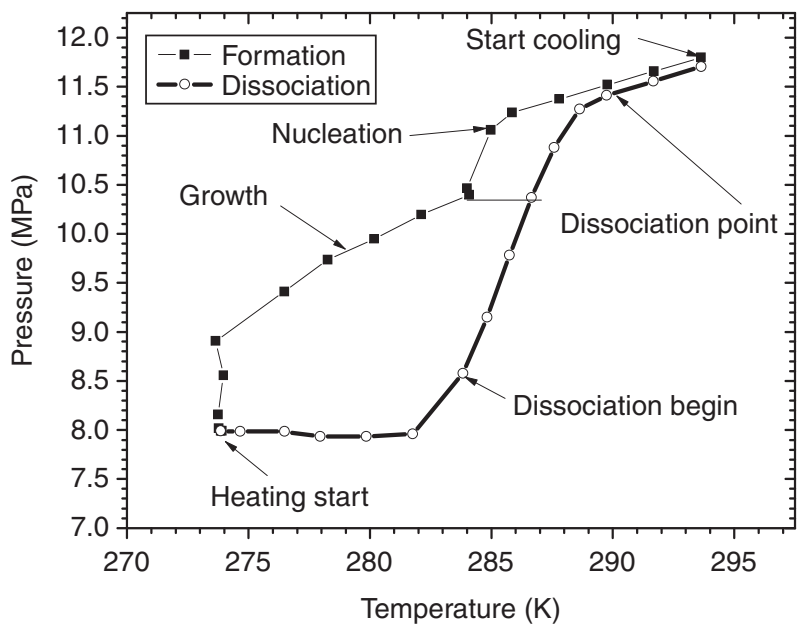

Figure 6

Pressure temperature profile of methane hydrate formation and dissociation in the presence of $10 \%$ bentonite clay and $10 \%$ silica sand (mesh size 52-60) in SSW.
Experiments were also performed with silica sand with variation in grain size to observe its effect on methane hydrate formation and dissociation. It is observed that the hydrate formation temperature is not much affected upon variation in the size of silica sand (Tab. 3). Higher subcooling (14.44 K) is required to initiate hydrate formation in the presence of silica sand than that of hydrate formation in the presence of bentonite clay suspension (Fig. 3,4). These results suggest that hydrate formation is greatly inhibited by silica sand, while the presence of bentonite clay thermodynamically promotes hydrate formation. The amount of gas consumed during hydrate formation is found to be reduced in the presence of silica (Tab. 3). Earlier studies also showed that silica particles exhibit thermodynamic inhibition during methane and natural gas hydrate formation [18, 19].

\subsection{Formation of Hydrate in the Presence of a Mixture of Silica Sand and Bentonite Clay}

Hydrate formation was also studied in the presence of a mixture of silica sand and bentonite clay under the same experimental conditions of temperature and pressure, with variation in the grain size of the sand, to observe the effect of particle size on methane hydrate formation and dissociation. It can be seen from Figure 5 that in addition to pressure drop at $284.85 \mathrm{~K}$, a fall in pressure is again observed at different temperatures depending on the grain size of the sand. This result indicates that there is an obvious effect of the grain size of silica sand on methane hydrate formation.

Figure 6 shows the variation in the temperature and pressure of methane hydrate formation and dissociation in the presence of $10 \%$ bentonite clay and $10 \%$ silica sand of mesh size 52-60. It can be seen that the first pressure drop is observed at $284.85 \mathrm{~K}$, which is due to bentonite clay as it was observed in the earlier case, and again a sharp drop in pressure at $273.71 \mathrm{~K}$ is observed (Fig. 6, Tab. 4). Figure 7 illustrates the effect of silica sand of mesh size 60-100 present in the test sample with $10 \%$ bentonite clay and $10 \%$ silica sand. Pressure drop at two different temperatures is observed. Drop in pressure occurs at $284.85 \mathrm{~K}$ and $274.55 \mathrm{~K}$ on account of bentonite clay and silica sand, respectively. It can be seen that in all the four different sets of experimental conditions, pressure drop at $284.85 \mathrm{~K}$ is found in all cases, while the formation temperature shifts to higher temperatures when the mesh size of the silica sand is varied from smaller to larger (Fig. 8). Also, it can be noted that the highest drop in pressure occurred in a test sample with silica sand of mesh size 60-100 compared with that of test samples with silica sand of smaller mesh sizes (Tab. 4). These results indicate that a process sample containing a mixture of silica sand and bentonite clay is relatively more effective for encapsulation of methane in hydrate compared with samples containing only bentonite clay or silica sand (Tab. 4, Fig. 8).

It can be seen that as the size of the silica sand is decreased, the growth temperature of methane hydrate 
TABLE 4

Nucleation temperature, initial cell pressure, growth temperature and pressure drop during hydrate formation in the presence of bentonite clay and silica sand

\begin{tabular}{|c|c|c|c|c|}
\hline Test sample & $\begin{array}{c}\text { Initial cell pressure } \\
(\mathrm{MPa})\end{array}$ & $\begin{array}{l}\text { Nucleation temperature } \\
(\mathrm{K})\end{array}$ & $\begin{array}{l}\text { Growth temperature } \\
(\mathrm{K})\end{array}$ & $\begin{array}{c}\text { Pressure drop } \Delta P \\
\text { (MPa) }\end{array}$ \\
\hline $10 \%$ bentonite in SSW & 11.54 & 284.85 & 283.70 & 1.13 \\
\hline $\begin{array}{l}10 \% \text { bentonite } \\
+10 \% \text { silica sand } \\
(\text { mesh size } 30-52) \text { in SSW }\end{array}$ & 11.54 & 284.85 & $\begin{array}{l}283.70 \\
272.91\end{array}$ & 3.80 \\
\hline $\begin{array}{l}10 \% \text { bentonite } \\
+10 \% \text { silica sand } \\
(\text { mesh size } 52-60) \text { in } \mathrm{SSW}\end{array}$ & 11.54 & 284.85 & $\begin{array}{l}283.70 \\
273.65\end{array}$ & 3.25 \\
\hline $\begin{array}{l}10 \% \text { bentonite } \\
+10 \% \text { silica sand } \\
(\text { mesh size } 60-100) \text { in } \mathrm{SSW}\end{array}$ & 11.54 & 284.85 & $\begin{array}{l}283.70 \\
274.55\end{array}$ & 4.24 \\
\hline
\end{tabular}

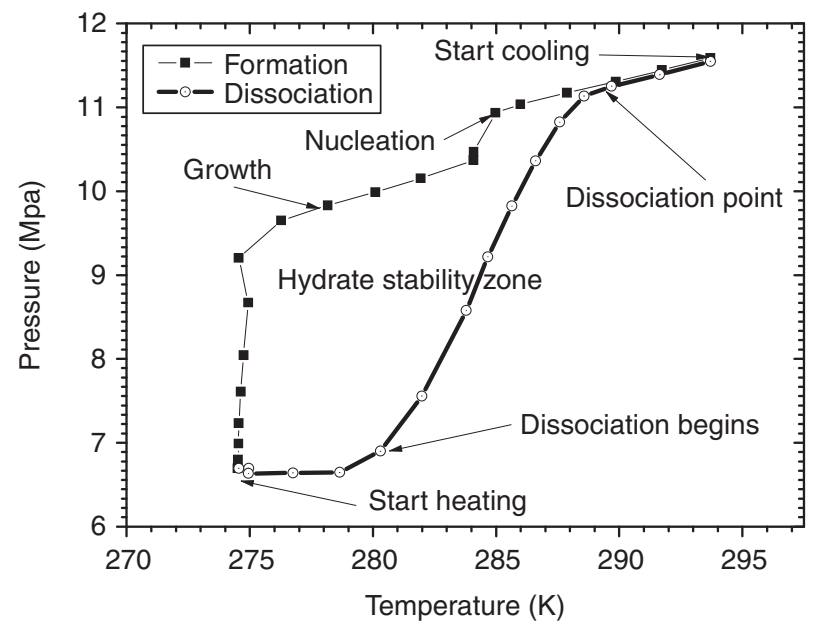

Figure 7

Pressure temperature profile of methane hydrate formation and dissociation in the presence of $10 \%$ bentonite clay and $10 \%$ silica sand (mesh size 60-100) in SSW.

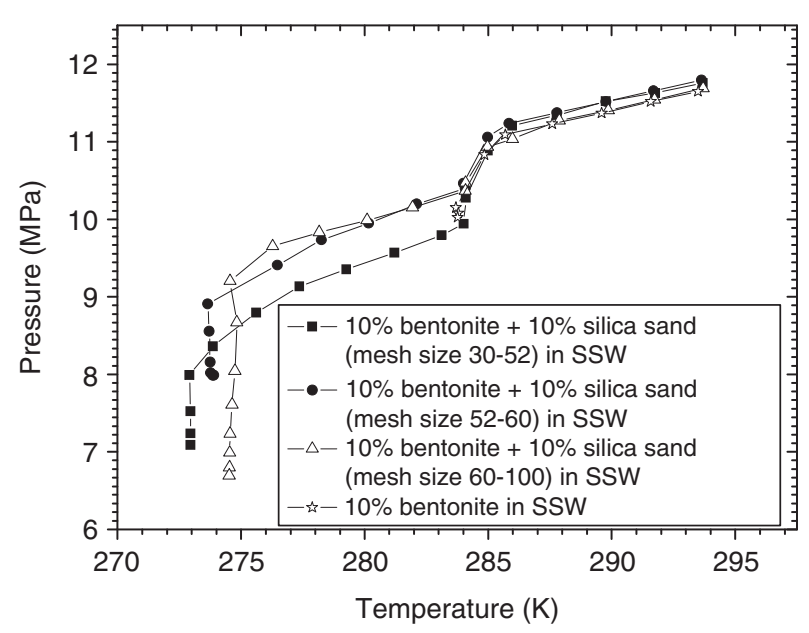

Figure 8

Comparative pressure temperature profile of methane hydrate formation in the presence of $10 \%$ bentonite clay and $10 \%$ silica sand. is shifted to a higher temperature, and simultaneously enhances the encapsulation of methane gas inside the hydrate. It can also be seen that hydrate formation occurred in multiple stages (Fig. 8). Similar phenomena were observed by other authors [20, 21]. Silica sands with smaller mesh size have a larger surface area since the surface area is inversely related to particle size [22]. As a result, water with silica sand with a large mesh size will be subjected to a greater influence of the silica surface than that with a smaller mesh size of the silica sand. This implies that the proportion of water available for hydrate formation may vary with the size of the sand. The properties of bulk water are different from those of water with electrolytes, sands, silts and clays, effectively affecting hydrate formation. The particle size plays a very crucial role in determining hydrate saturation in sediments. Bagherzadeh et al. [23] studied methane hydrate formation in an unconsolidated bed of silica sand of different particle sizes, employing the magnetic imaging technique. It is observed that hydrate formation is not uniform in such a porous medium, but the rate of hydrate formation is found to be faster in a bed of low water content and sand of smaller particle size. 


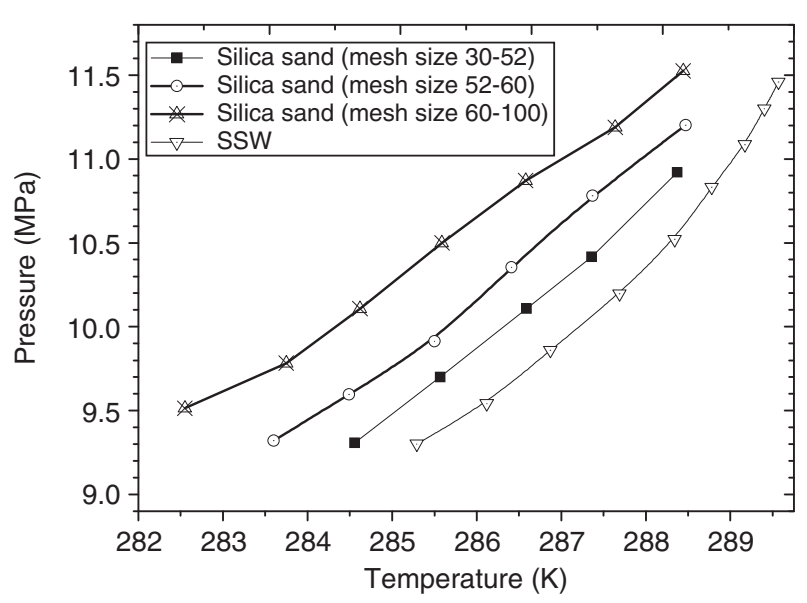

Figure 9

Methane hydrate phase equilibrium data in the presence of silica sand in synthetic seawater of $3.55 \%$ TDS.

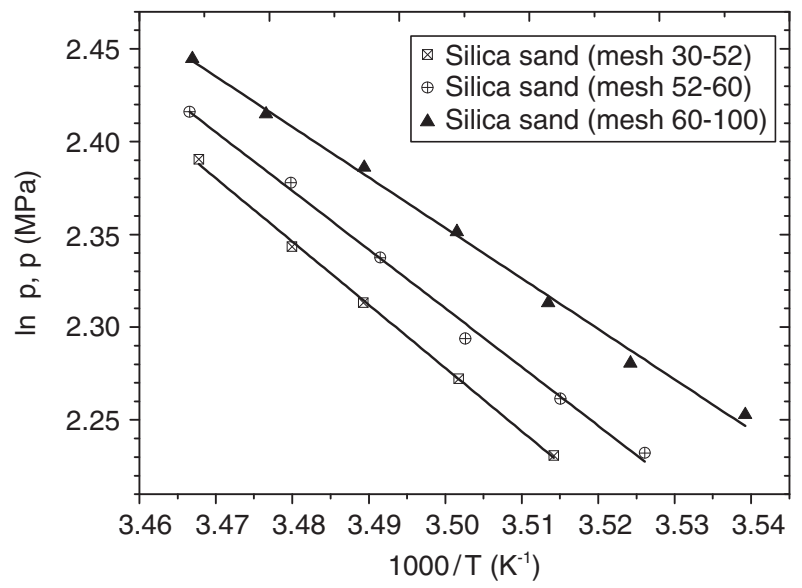

Figure 10

Semilogarithmic plot of phase equilibrium data of methane hydrate in the presence of silica sand of different mesh sizes.

\subsection{Dissociation of Hydrate in the Presence of Silica Sand}

The phase equilibrium of methane hydrate is significantly influenced by the presence of silica sand of different mesh sizes, because the liquid to solid transition is depressed to a lower temperature at any given pressure. The phase equilibrium curves are shifted to a relatively high-pressure and low-temperature zone as the particle size of the sand is decreased. These curves suggest that methane hydrate formed in the presence of sand with a smaller particle size would be more stable in the higher pressure zone only than hydrate formed in the presence of sand with a larger particle size (Fig. 9). There is a linear relationship between temperature and pressure. As the temperature increases, the pressure also increases during dissociation of the hydrate (Fig. 10). Such behavior of the hydrate equilibrium curves in the presence of silica sand of different mesh sizes may be induced by the high curvature of the solid-liquid interface [24].

Based on phase equilibrium data, it is possible to determine the enthalpy of hydrate dissociation using the Clausius-Clapeyron equation. The calculated enthalpy of hydrate dissociation of methane hydrate at a corresponding equilibrium temperature and pressure is presented in Table 5. The enthalpy of dissociation of methane hydrate is affected by the presence of silica sand. The dissociation enthalpy was found to vary with the grain size of the sand, since the phase equilibrium temperature and pressure of the hydrate are affected. This results in a change in the value of the compressibility factor ( $Z$, calculated using the PengRobinson equation of state) of the gas.

\subsection{Dissociation of Hydrate in the Presence of a Mixture of Silica Sand and Bentonite Clay}

The phase equilibria of methane hydrate in the presence of bentonite clay and a mixture of silica sand and bentonite clay are shown in Figure 11. The phase equilibrium curve of methane hydrate in the presence of bentonite clay is shifted to a high-pressure region compared with the equilibrium curves of hydrate in the presence of a mixture of bentonite clay and silica sand.

It is clear that methane hydrate phase equilibrium is shifted to a low-pressure and high-temperature region, indicating higher stability in the presence of both bentonite clay and silica sand (Fig. 11). It can also be noted that there is no significant effect of the particle size of silica sand on the phase equilibrium of methane hydrate in a mixture of sand and clay. The phase equilibrium data of temperature and pressure obtained in the presence of bentonite clay and silica sand are presented in Table 6 and plotted as $\ln (p)$ versus $1 / T$ (Fig. 12). It is also important to note that on varying the size of sand in a mixture of sand and bentonite clay the phase equilibrium curves are not significantly affected, while methane gas from the hydrate is released slowly on heating in a wide range of temperatures compared with methane gas from the hydrate 
TABLE 5

Calculated dissociation enthalpy at different equilibrium points of pressure $\left(P_{\text {diss }}\right)$ and temperature $\left(T_{\text {diss }}\right)$ in the presence of silica sand

\begin{tabular}{|c|c|c|c|c|}
\hline Test sample & $P_{\text {diss }}(\mathrm{Mpa})$ & $T_{\text {diss }}(\mathrm{K})$ & $Z$ & $\Delta H(\mathrm{~kJ} / \mathrm{mol})$ \\
\hline \multirow{4}{*}{ SSW (3.55\% TDS) } & 9.30 & 285.29 & 0.8085 & 162.0258 \\
\hline & 9.54 & 286.12 & 0.8064 & 162.6113 \\
\hline & 9.85 & 286.87 & 0.8055 & 163.3407 \\
\hline & 10.19 & 287.69 & 0.801 & 163.4212 \\
\hline \multirow{4}{*}{$\begin{array}{l}10 \% \text { silica sand } \\
\text { (mesh 30-52) }\end{array}$} & 9.69 & 285.57 & 0.8032 & 161.3015 \\
\hline & 10.10 & 286.59 & 0.8009 & 162.0695 \\
\hline & 10.42 & 287.36 & 0.7994 & 162.6956 \\
\hline & 10.92 & 288.37 & 0.7969 & 163.4062 \\
\hline \multirow{4}{*}{$\begin{array}{l}10 \% \text { silica sand } \\
\text { (mesh 52-60) }\end{array}$} & 9.91 & 285.5 & 0.8003 & 160.6349 \\
\hline & 10.35 & 286.41 & 0.7976 & 161.1853 \\
\hline & 10.78 & 287.37 & 0.7956 & 161.9343 \\
\hline & 11.20 & 288.47 & 0.7846 & 161.0031 \\
\hline \multirow{4}{*}{$\begin{array}{l}10 \% \text { silica sand } \\
(\text { mesh } 60-100)\end{array}$} & 9.51 & 282.55 & 0.7975 & 156.5563 \\
\hline & 9.78 & 283.75 & 0.7972 & 157.9229 \\
\hline & 10.10 & 284.62 & 0.7956 & 158.6412 \\
\hline & 10.49 & 285.59 & 0.7938 & 159.4376 \\
\hline
\end{tabular}

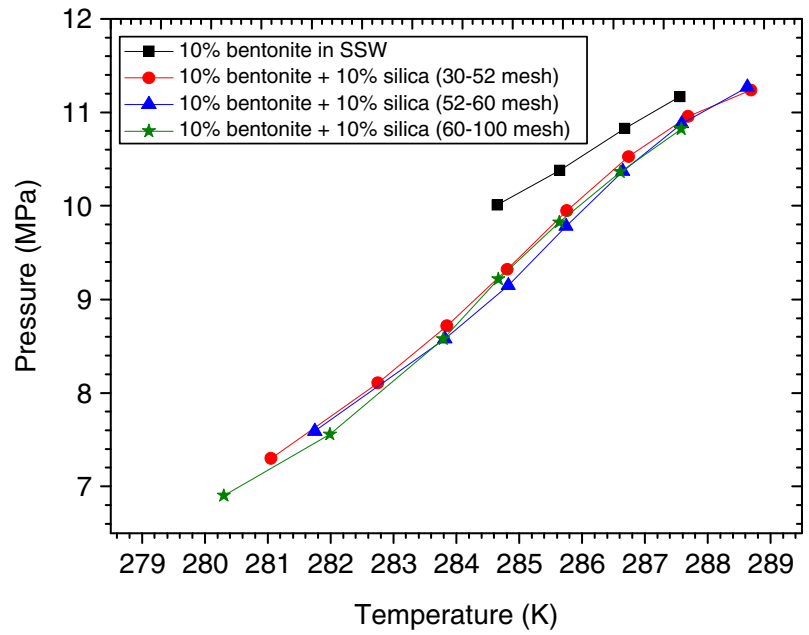

Figure 11

Methane hydrate phase equilibrium data in the presence of bentonite and silica sand.

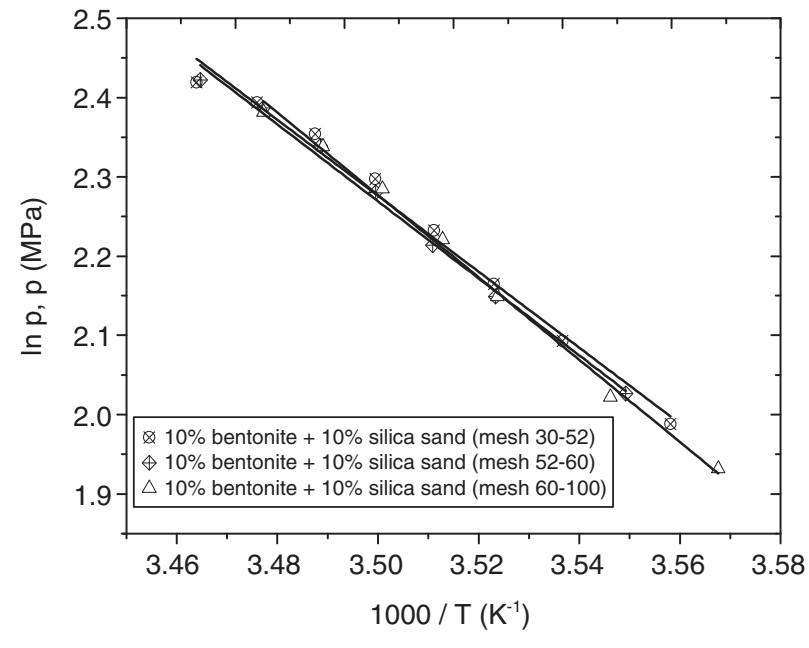

Figure 12

Semilogarithmic plot of phase equilibrium data of methane hydrate in the presence of a mixture of bentonite clay and silica sand. with bentonite clay. There is not much effect of the particle size of the sand on dissociation enthalpy; however, the process sample with sand affects the enthalpy of dissociation appreciably more than the test sample with clay alone. Relatively more heat is required to dissociate the hydrate formed in the presence of both 
TABLE 6

Calculated dissociation enthalpy at different equilibrium points of pressure $\left(P_{\text {diss }}\right)$ and temperature $\left(T_{\text {diss }}\right)$ in the presence of silica sand and bentonite clay

\begin{tabular}{|c|c|c|c|c|}
\hline Test sample & $P_{\text {diss }}(\mathrm{Mpa})$ & $T_{\text {diss }}(\mathrm{K})$ & $Z$ & $\Delta H(\mathrm{~kJ} / \mathrm{mol})$ \\
\hline \multirow{3}{*}{$10 \%$ bentonite in SSW } & 10.38 & 285.65 & 0.8568 & 21.15 \\
\hline & 10.83 & 286.68 & 0.8431 & 22.19 \\
\hline & 11.60 & 287.56 & 0.8336 & 21.34 \\
\hline \multirow{5}{*}{$\begin{array}{l}10 \% \text { bentonite }+ \\
10 \% \text { silica sand } \\
(\text { mesh } 30-52) \text { in SSW }\end{array}$} & 7.30 & 281.05 & 0.8621 & 167.32 \\
\hline & 8.10 & 282.75 & 0.8367 & 164.50 \\
\hline & 9.32 & 284.81 & 0.8202 & 163.78 \\
\hline & 10.52 & 286.74 & 0.8021 & 162.49 \\
\hline & 11.23 & 288.69 & 0.7921 & 162.80 \\
\hline \multirow{5}{*}{$\begin{array}{l}10 \% \text { bentonite } \\
+10 \% \text { silica sand } \\
(\text { mesh } 52-60) \text { in SSW }\end{array}$} & 7.59 & 281.75 & 0.8533 & 166.49 \\
\hline & 9.14 & 284.83 & 0.8338 & 166.52 \\
\hline & 9.78 & 285.75 & 0.8236 & 165.62 \\
\hline & 10.36 & 286.65 & 0.8126 & 164.51 \\
\hline & 11.27 & 288.63 & 0.7982 & 163.98 \\
\hline \multirow{5}{*}{$\begin{array}{l}10 \% \text { bentonite } \\
+10 \% \text { silica sand } \\
(\text { mesh } 60-100) \text { in SSW }\end{array}$} & 6.90 & 280.3 & 0.8751 & 168.87 \\
\hline & 7.55 & 281.99 & 0.8554 & 167.21 \\
\hline & 8.57 & 283.79 & 0.8223 & 162.94 \\
\hline & 9.21 & 284.67 & 0.8134 & 162.25 \\
\hline & 10.36 & 286.61 & 0.8009 & 162.09 \\
\hline
\end{tabular}

sand and clay compared with hydrate formed in the presence of clay alone (Tab. 6).

\section{KINETICS OF HYDRATE FORMATION}

\subsection{Measurement of Induction Time}

To measure the induction time of hydrate formation, the process sample is adjusted to the temperature and pressure where hydrate is completely dissociated, i.e. the dissociation point or equilibrium point of the hydrate (Fig. 3) and allows the process sample to achieve that temperature where hydrate begins to form, i.e. the nucleation temperature. The time taken during this process is the induction time or nucleation time. The temperaturepressure response during the measurement of the induction time is shown in Figure 13.

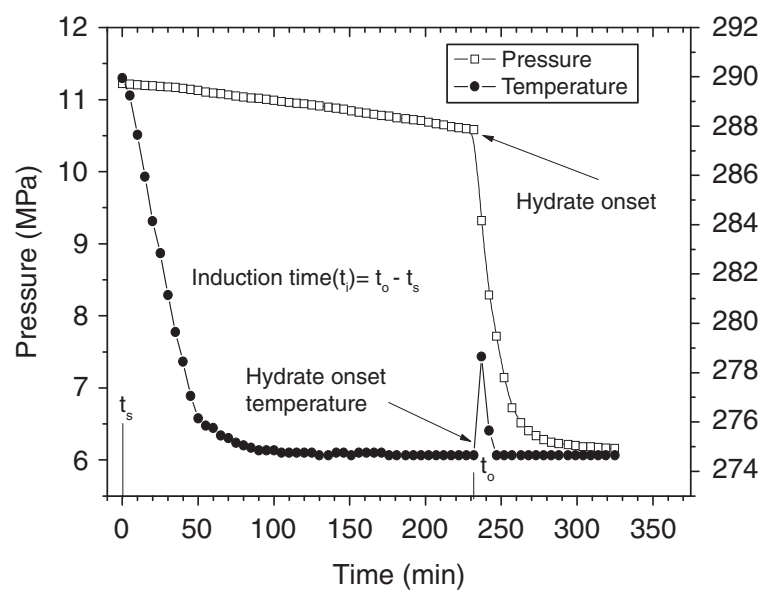

Figure 13

Response of temperature and pressure during hydrate formation of the test sample with $10 \%$ bentonite clay and $10 \%$ silica sand of mesh size 60-100. 
The induction time measured is the difference in the hydrate onset time $\left(t_{o}\right)$ and the start time $\left(t_{s}\right)$ of the experiment where hydrate is completely dissociated, i.e. the dissociation point of the hydrate. The hydrate onset time is taken as $t_{o}$, where the pressure suddenly falls, followed by an increase in the cell temperature due to the latent heat of crystallization, while $t_{s}$ is the time of the start of experiment from the dissociation point. The spike in temperature is observed in all the experiments. This is due to the release of the latent heat of crystallization when water and methane molecules rearrange into the hydrate state. The heat released during the process of hydrate formation is not the same in all cases. It depends on the type of medium in which the hydrate formers (water and methane) are allowed to crystallize. The induction time is measured under different subcooling conditions.

The induction time measured during hydrate formation in the presence of silica sand is presented in Table 7. It is found that the silica sand of smaller mesh size has a stronger impact on the induction time of hydrate formation, as it lengthens the induction time of hydrate nucleation, than that of silica sand with larger mesh size. The induction time is also found to be dependent on the subcooling of hydrate formation (Tab. 7).

Higher subcooling shortens the induction time, while lower subcooling lengthens it. The induction time of hydrate formation is shorter for the test sample with a mixture of bentonite clay and silica sand but higher than that of the sample with bentonite clay alone. The presence of bentonite clay decreases the induction time of hydrate formation $(T a b .8)$. The induction time of hydrate formation also depends on the rate of cooling: the slower the cooling rate, the longer the nucleation time. A slow cooling rate leads to lower subcooling and a longer nucleation time [12].

\subsection{Gas Consumption}

The number of moles of gas consumed during hydrate formation are computed using a real gas equation:

$$
\Delta n=n_{i}-n_{f}=V R P_{i} Z_{i} T_{i}-P_{f} Z_{f} T_{f}
$$

where $\Delta n$ is the amount of gas consumed when hydrates form, $V$ is the gas volume, $P_{i}, T_{i}$ and $P_{f}, T_{f}$ are the pressure and temperature in initial and final conditions, and $R$ is the universal gas constant. Compressibility factors $\left(Z_{i}, Z_{f}\right)$ were measured using the Peng-Robinson equation of state at the respective pressure and temperature.

Silica sand with smaller particle size is found to increase gas consumption. This consumption of gas is more pronounced for the test sample with the smallest particle size of silica sand. It is observed that hydrate formation takes place rapidly in a short duration after nucleation, and also the slope of the curves seems to be almost the same, indicating a constant formation rate (Fig. 14, 15). The addition of bentonite clay to the silica sand sample enhances the rate of gas consumption.

The conversion rate of methane into hydrate is also dominated by the cooling process. A higher cooling rate decreases the methane conversion rate [12].

TABLE 7

Measured formation temperature $(T)$, dissociation temperature $\left(T_{\text {diss }}\right)$, subcooling $\left(\Delta T=T_{\text {diss } / \text { eq }}-T\right)$ and induction time of hydrate formation in silica sand

\begin{tabular}{l|c|c|c|c}
\hline \multirow{2}{*}{ Test sample } & $T(\mathrm{~K})$ & $T_{\text {diss }}(\mathrm{K})$ & $\Delta T(\mathrm{~K})$ & Induction time (min) \\
\hline \multirow{3}{*}{$\begin{array}{l}\text { 10\% silica sand } \\
\text { (mesh size 30-52) in }\end{array}$} & 272.27 & 285.57 & 13.3 & 418 \\
\cline { 2 - 5 } & 272.27 & 286.59 & 15.09 & 389 \\
\cline { 2 - 5 } & 272.27 & 287.36 & 16.1 & 348 \\
\hline \multirow{3}{*}{$\begin{array}{l}\text { 10\% silica sand } \\
\text { (mesh size 52-60) } \\
\text { in SSW10\% }\end{array}$} & 272.27 & 288.37 & 13.4 & 307 \\
\cline { 2 - 5 } & 270.2 & 283.6 & 14.29 & 305 \\
\hline \multirow{2}{*}{$\begin{array}{l}\text { Silica sand } \\
\text { (mesh size 60-100) }\end{array}$} & 270.2 & 284.49 & 15.3 & 334 \\
\cline { 2 - 5 } in SSW & 271.99 & 285.5 & 13.6 & 278 \\
\hline
\end{tabular}


TABLE 8

Measured formation temperature ( $T)$, dissociation temperature $\left(T_{\text {diss }}\right)$, subcooling $\left(\Delta T=T_{\text {diss }}-T\right)$ and induction time of hydrate formation in the presence of both bentonite clay and silica sand

\begin{tabular}{|c|c|c|c|c|}
\hline Test sample & $T(\mathrm{~K})$ & $T_{\text {diss }}(\mathrm{K})$ & $\Delta T(\mathrm{~K})$ & Induction time $(\mathrm{min})$ \\
\hline \multirow{3}{*}{$10 \%$ bentonite in SSW } & 284.85 & 286.68 & 1.83 & 15 \\
\hline & 283.85 & 285.65 & 1.80 & 20 \\
\hline & 283.85 & 284.65 & 0.80 & 25 \\
\hline \multirow{5}{*}{$\begin{array}{l}10 \% \text { bentonite } \\
+10 \% \text { silica sand } \\
(\text { mesh size } 30-52) \text { in SSW }\end{array}$} & 272.91 & 283.85 & 10.94 & 384 \\
\hline & 272.91 & 284.81 & 11.9 & 375 \\
\hline & 272.91 & 285.76 & 12.85 & 356 \\
\hline & 272.91 & 286.74 & 13.83 & 334 \\
\hline & 272.91 & 287.69 & 14.78 & 323 \\
\hline \multirow{4}{*}{$\begin{array}{l}10 \% \text { bentonite } \\
+10 \% \text { silica sand } \\
(\text { mesh size } 52-60) \text { in SSW }\end{array}$} & 273.65 & 283.82 & 10.17 & 343 \\
\hline & 273.65 & 284.83 & 11.18 & 324 \\
\hline & 273.65 & 285.75 & 12.1 & 310 \\
\hline & 273.65 & 286.65 & 13.0 & 292 \\
\hline \multirow{4}{*}{$\begin{array}{l}10 \% \text { bentonite } \\
+10 \% \text { silica sand } \\
(\text { mesh size } 60-100) \text { in } \mathrm{SSW}\end{array}$} & 274.55 & 281.99 & 7.44 & 289 \\
\hline & 274.55 & 284.67 & 10.12 & 268 \\
\hline & 274.55 & 286.61 & 12.06 & 241 \\
\hline & 274.55 & 287.58 & 13.03 & 232 \\
\hline
\end{tabular}

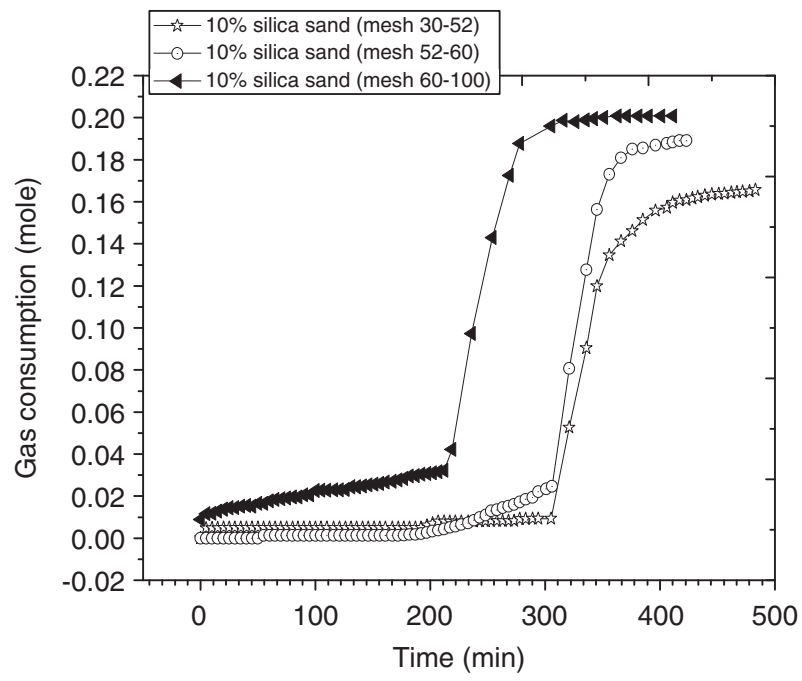

Figure 14

The rate of gas consumption during hydrate formation in the presence of silica sand in SSW.

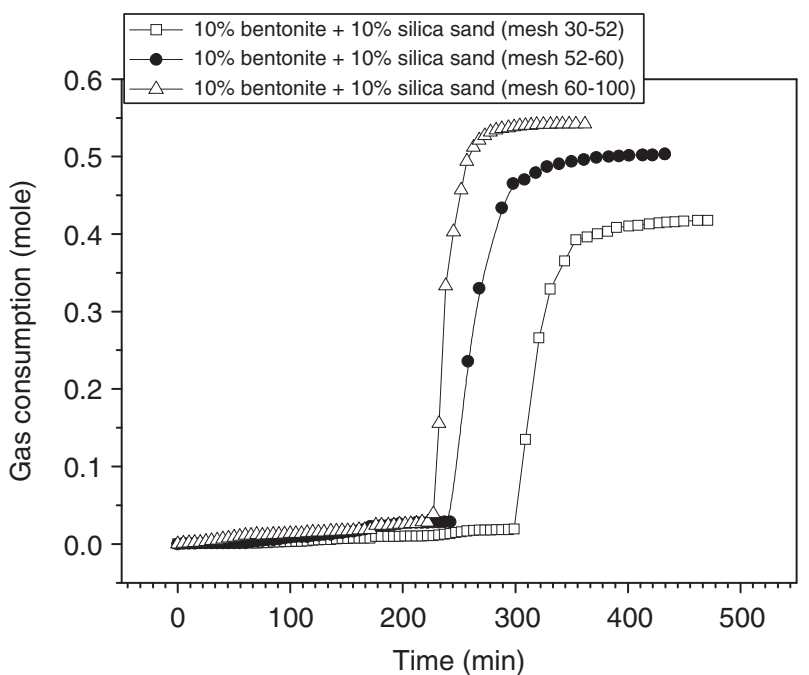

Figure 15

The rate of gas consumption during hydrate formation in the presence of both silica sand and bentonite clay in SSW.
Several authors just estimated the gas hydrate distribution and saturation level in sediments because natural gas hydrate samples have rarely been recovered intact. They revealed that particle size does play an important role in affecting the saturation level of hydrate in sediments. The conversion of methane into 
hydrate depends on water saturation, and the particle size of sand and clay concentration in sediments $[14,25-26]$.

\section{CONCLUSIONS}

The effects of bentonite clay, silica sand and the grain size of silica sand were studied on methane hydrate formation and dissociation. The addition of bentonite clay to the test sample with silica sand greatly affects the hydrate formation and dissociation temperature. Hydrate formation is shifted to a lower temperature in the presence of silica sand compared with test samples with bentonite clay and a mixture of silica sand and bentonite clay. The phase equilibrium curve is not appreciably affected upon variation in the size of the sand of test samples with a mixture of sand and clay; however, it is significantly affected by variation in the size of silica sand in the test sample with silica sand alone. There is no significant effect of the particle size of the sand on enthalpy; however, the process sample with sand affects the enthalpy of dissociation appreciably more than the test samples with clay alone. Relatively more heat is required to dissociate hydrate in the presence of sand compared with the hydrate in the presence of clay. Silica sand of smaller mesh size delayed the nucleation time of hydrate formation more than that of sand with larger mesh size. Addition of bentonite clay to the sample with silica sand significantly reduces the induction time.

\section{ACKNOWLEDGMENTS}

We gratefully acknowledge the financial assistance provided by the University Grants Commission, New Delhi, India, under the Special Assistance Program (SAP) to the Department of Petroleum Engineering, Indian School of Mines, Dhanbad, India.

\section{REFERENCES}

1 Kvenvolden K.A. (1995) A review of the geochemistry of methane in natural gas hydrates, Org. Geochem. 23, 997-1008.

2 Sloan E.D. (1998) Clathrate Hydrate of Natural Gases, 2nd ed., Marcel Deckker, New York.

3 Sun R., Duan Z. (2007) An accurate model to predict the thermodynamic stability of methane hydrate and methane solubility in marine environments, Chem. Geol. 244, $248-262$
4 Handa Y.P. (1990) Effect of hydrostatic pressure and salinity on the stability of gas hydrates, J. Phys. Chem. 94, 6, 2652-2657.

5 Dixon J.E., Clague D.A., Stolper E.M. (1991) Degassing history of water, sulfur, and carbon in submarine lavas from Kilauea Volcano, Hawaii, J. Geol. 99, 371-394.

6 Ginsburg G.D. (1996) First master workshop of gas hydrates: relevance of world margin Stability and Climate Change, Gent, Belgium, pp. 123-147.

7 Kvenvolden K.A. (1996) First Master Workshop on Gas Hydrates: Relevance to World Margin Stability and Climate Change, Gent, Belgium, pp. 39-80.

8 Handa Y.P., Stupin D.Yu (1992) Thermodynamic properties and dissociation characteristics of methane and propane hydrates in 70 - $\AA$-radius silica gel pores, J. Phys. Chem. 96, 8599-8603.

9 Uchida T., Takeya S., Chuvilin E.M., Ohmura R., Nagao J., Yakushev V.S., Istomin V.A., Minagawa H., Ebinuma T., Narita H. (2004) Decomposition of methane hydrates in sand, sandstone, clays, and glass beads, J. Geophys. Res.: Solid Earth 109, B05206, 1-12. doi:10.1029/ 2003JB002771.

10 Turner D.J., Cherry R.S., Sloan E.D. (2005) Sensitivity of methane hydrate phase equilibria to sediment pore size, Fluid Phase Equilib. 228/229, 505-510.

11 Li G., Li X.-S., Tang L.-G., Feng Z.-P., Fan S.-S., Zhang Y. (2007) Experimental Study on the Effect of Temperature Cooling Profile on Methane Hydrate Formation, Chin. J. Process. Eng. 7, 4, 723-727.

12 Guanli J., Qingbai W., Jing Z. (2010) Effect of cooling rate on methane hydrate formation in media, Fluid Phase Equilib. 298, 225-230.

13 Clennell M.B., Hovland M., Booth J.S., Henry P., Winters W.J. (1999) Formation of natural gas hydrates in marine sediments: 1 . Conceptual model of gas hydrate growth conditioned by host sediment properties, J. Geophys. Res. 104, B10, 22985-23003.

14 Kang S.-P., Lee J.-W. (2010) Formation Characteristics of Synthesized Natural Gas Hydrates in Meso- and Macroporous Silica Gels, J. Phys. Chem. B. 114, 20, 6973-6978.

15 Li X.-S., Zhang Y. (2011) Study on Dissociation Behaviors of Methane Hydrate in Porous Media Based on Experiments and Fractional Dimension Shrinking-Core Model, Ind. Eng. Chem. Res. 50, 8263-8271.

16 Gieskes J.M. (1975) Chemistry of Interstitial Waters of Marine Sediments, Annu. Rev. Earth Planetary Sci. 3, 433-453.

17 Saw V.K., Ahmad I., Mandal A., Udayabhanu G., Laik S. (2012) Methane hydrate formation and dissociation in synthetic seawater, J. Nat. Gas Chem. 21, 6, 625-632.

18 Aladko E.Y., Dyadin Y.A., Fenelonov V.B., Larionov E. G., Mel'gunov M.S., Manakov A.Y., Nesterov A.N., Zhurko F.V. (2004) Dissociation Conditions of Methane Hydrate in Mesoporous Silica Gels in Wide Ranges of Pressure and Water Content, J. Phys. Chem. B 108, 42, 16540-16547.

19 Kang S.P., Seo Y. (2008) International Gas Union Research (IGRC), Paris, 1-10. 
20 Linga P., Haligva C., Nam S.C., Ripmeester J.A., Englezos P. (2009) Recovery of Methane from Hydrate Formed in a Variable Volume Bed of Silica Sand Particles, Energy Fuels 23, 11, 5508-5516.

21 Prasad P.S.R., Chari V.D., Sharma D.V.S.G.K., Murthy S.R. (2012) Effect of silica particles on the stability of methane hydrates, Fluid Phase Equilib. 318, 110-114.

22 Bird R.B., Stewart W.E., Lightfoot E.N. (2002) Transport Phenomena, Wiley, New York.

23 Bagherzadeh A.S., Moudrakovski I.L., Ripmeester J.A., Englezos P. (2011) Magnetic Resonance Imaging of Gas Hydrate Formation in a Bed of Silica Sand Particles, Energy Fuels 25, 7, 3083-3092.

24 Anderson R., Llamedo M., Tohidi B., Burgass R.W. (2003) Experimental Measurement of Methane and Carbon Dioxide Clathrate Hydrate Equilibria in Mesoporous Silica, J. Phys. Chem. B 107, 15, 3507-3514.
25 Riestenberg D., West W., Lee S., McCallum S., Phelps T.J. (2003) Sediment surface effects on methane hydrate formation and dissociation, Marine Geology 198, 1-2, 181-190.

26 Lu H., Kawasaki T., Ukita T., Moudrakovski I., Fujii T., Noguchi S., Shimada T., Nakamizu M., Ripmeester J., Ratcliffe C. (2011) Particle size effect on the saturation of methane hydrate in sediments - Constrained from experimental results, Marine Petrol. Geol. 28, 10, 1801-1805.

Manuscript accepted in October 2013 Published online in March 2014

Cite this article as: V.K. Saw, G. Udayabhanu, A. Mandal and S. Laik (2014). Methane Hydrate Formation and Dissociation in the Presence of Silica Sand and Bentonite Clay, Oil Gas Sci. Technol 70, 6, 1087-1099. 